\title{
Introduction: Judicial Dialogue on the Return Directive - Catalyst for Changing Migration Governance?*
}

GALINA CORNELISSE AND MADALINA MORARU

This book analyses how courts and judicial dialogue shape return policies in the European Union. The way in which states have traditionally dealt with irregular migration has for many decades been characterised by extensive executive discretion, with a very limited role for the judiciary. ${ }^{1}$ This book argues that in the European Union, the adoption of the Return Directive ${ }^{2}$ brought a significant change to the physiognomy of immigration law in this respect. In particular, it has brought expulsion procedures under judicial scrutiny and thus within the rule of law. ${ }^{3}$ Indeed, seeing that EU law enforcement is decentralised and relies for a large extent on the bottom-up engagement of individuals claiming their rights, the Directive empowered domestic courts to venture into a field that had hitherto been dominated by the executive. With domestic judges able to assume the position of 'natural judges' ${ }^{4}$ of the Directive, it was predictable that the deference shown by domestic courts to the executive would wane. And certainly, in many

\footnotetext{
* The chapters of the volume were concluded in 2019 and were largely based on the data collected within the REturn Directive DIALogue - REDIAL project (2014-2016).

${ }^{1}$ While other areas of migration law, most significantly asylum and family related migration, have over the past decades witnessed the institutionalisation of important limits to the state's exclusionary powers by the judiciary, the return and removal of irregular migrants has remained until recently largely outside the purview of courts. See G Cornelisse, Immigration Detention and Human Rights: Rethinking Territorial Sovereignty (Leiden and Boston, MA, Brill, 2010), in particular ch 5. See also G Cornelisse, 'Case C-357/09 PPU, Proceedings Concerning Said Shamilovich Kadzoev (Huchbarov), Judgment of the European Court of Justice (Grand Chamber) of 30 November 2009" (2011) 48 CML Rev 925, 941; M de Somer, Precedents and Judicial Politics in EU Immigration Law (Basingstoke, Palgrave, 2019); C Costello, The Human Rights of Migrants and Refugees in European Law (Oxford, Oxford University Press, 2015).

${ }^{2}$ Directive 2008/115/EC of the European Parliament and the Council, of 16 December 2008, on common standards and procedures in Member States for returning illegally staying third-country nationals [2008] OJ L348 ('Return Directive').

${ }^{3}$ For judicial scrutiny as an important component of the rule of law, see RS Summers, 'The Principles of the Rule of Law' (1999) 74 Notre Dame Law Review 1691, 1694.

${ }^{4}$ The term was first used by Tzanakopoulos in relation to judges implementing international law. See A Tzanakopoulos, "Domestic Courts as the "Natural Judge" of International Law: A Change in Physiognomy' in J Crawford and S Nouwen (eds), Select Proceedings of the European Society of International Law, vol 3 (Oxford, Hart Publishing, 2010) 155-68.
} 
Member States, domestic courts' application of the Directive has constrained the executive in unforeseen ways, especially when these courts started to engage in judicial dialogue with the Court of Justice of the EU (CJEU) to ensure its correct interpretation and implementation. Cases such as Kadzoev, ${ }^{5} \mathrm{Zh}$ and $\mathrm{O},{ }^{6} \mathrm{El} \mathrm{Dridi},{ }^{7}$ Mahdi, ${ }^{8}$ Affum $^{9}$ and Arib $^{10}$ exemplify how such dialogue has strengthened the role of courts in scrutinising the choices made by governments on border control and expulsion, even under conditions of highly mediatised political pressures. ${ }^{11}$ Judicial dialogue on the implementation of the Return Directive has produced very real effects at both the EU and domestic level, such as limiting the criminalisation of irregular migration, prioritising voluntary departure over pre-removal detention, and providing for more judicial control over administrative detention and other coercive measures of immigration law enforcement. As such, it has ensured the checks and balances of state powers that usually exist in other fields of law, but were less present in immigration law before the entry into force of the Directive.

More generally, by clarifying the direct effect of certain provisions of the Return Directive, emphasising the EU principle of proportionality, and applying several rights guaranteed by the Charter of Fundamental Rights of the EU ('the Charter'), the engagement of and interaction among judges has brought into sharp focus that the exercise of migration control by the state (also when it concerns irregular migrants) impinges on the rights of individuals, and needs proper constitutional scrutiny. ${ }^{12}$ Judicial dialogue has thus enhanced procedural safeguards and the protection of individuals' fundamental rights. However, the extent to which the Return Directive has been able to shift the institutional configuration of the Member States when it comes to the enforcement of immigration powers shows diverse patterns, with some Member States' judiciaries having seized more control over administrative decision-making than others, and some more inclined to interact with EU law, the CJEU and other national courts than others.

\footnotetext{
${ }^{5}$ Case C-357/09 PPU Kadzoev ECLI:EU:C:2009:741.

${ }^{6}$ Case C-554/13 Zh. and O ECLI:EU:C:2015:377.

${ }^{7}$ Case C-61/11 PPU El Dridi ECLI:EU:C:2011:268.

${ }^{8}$ Case C-146/14 Mahd, ECLI:EU:C:2014:1320.

${ }^{9}$ Case C-47/15 Affum ECLI:EU:C:2016:408.

${ }^{10}$ Case C-444/17 Arib ECLI:EU:C:2019:220.

${ }^{11}$ See the attack by Italy's former interior minister, Matteo Salvini, on three individual judges over their rulings in immigration cases, The Guardian (6 June 2019) www.theguardian.com/world/2019/ jun/06/salvini-steps-up-attacks-on-italian-judges-who-challenge-him; see also Viktor Orban's attack on the European Court of Human Rights (ECtHR), see Euractiv (30 March 2017) www.euractiv.com/ section/global-europe/news/orban-attacks-the-european-court-of-human-rights-at-epp-congress/. The Affum and Arib cases were decided within the context of the 'Schengen crisis', see TA Börzel and T Risse, 'From the Euro to the Schengen Crises: European Integration Theories, Politicization, and Identity Politics' (2018) 25 Journal of European Public Policy 83-108.

${ }^{12} \mathrm{G}$ Cornelisse, 'The Constitutionalisation of Immigration Detention: Between EU Law and the European Convention on Human Rights', Global Detention Project Working Paper No 15 (October 2016).
} 
The chapters in this volume focus on the role of the judiciary in the implementation of the Return Directive in the Member States. Specifically, they zoom in on judicial interactions when courts decide cases that fall within the scope of the Directive. The book thus aims to shed light on the role played by the judiciary in one of the most important strongholds of national executives, and one of the most politically sensitive fields of EU law: return policy. ${ }^{13}$ A key question throughout the book is how domestic judges have exercised their role as ordinary judges of EU law, bound to give effect to sometimes opposing policy objectives, namely an effective return policy and the protection of fundamental rights, while also being obliged to act in accordance with general principles of EU law. In such a politically loaded area, it is inevitable that national courts face struggles when giving effect to the Directive, brought about by an awareness of the domestic and European political implications of their decisions. Furthermore, judges in Europe deciding in return cases manoeuvre an area that is not only characterised by the interaction between EU law and domestic law, but that is also subject to regulation from other legal orders, both global (UN), and regional (eg the ECHR). The chapters in this book will show that there are crucial differences in the way in which these courts and judges perceive their responsibility to ensure the effectiveness of EU law in this complex legal configuration, not only among the Member States' judiciaries, but also among the branches of the judiciary within single Member States. ${ }^{14}$ These differences have implications for the way in which the rights of irregular migrants are protected in Europe. Moreover, they raise pertinent questions as regards the role of the judiciary in the European legal constellation, which are not only relevant for assessing law and policy in the area of irregular migration, but also have wider implications for European integration at a time when European institutional dynamics are under increasing pressure. ${ }^{15}$ We will revisit these issues below.

In this introduction, we briefly explain the necessity of in-depth research into the role of courts and judicial dialogue in relation to the implementation of the Return Directive (section I). Second, we define 'judicial dialogue' as used in this volume, and explain our research design and the questions this book aims to

\footnotetext{
${ }^{13} \mathrm{ibid}$.

${ }^{14}$ See S Slama, 'Trois hautes juridictions nationales pour une directive: une interaction judiciaire en trompe l'œil', Chapter 14 in this volume.

${ }^{15}$ For a detailed discussion of such implications in the case of Schengen integration (drawing a parallel with monetary policies), see G Cornelisse, 'What's Wrong with Schengen? Border Disputes and the nature of Integration in the Area without Internal Borders' (2014) 51 CML Rev 741. For a discussion of how configurations of political authority are changing as a result of the partial transfer of lawmaking competence in immigration policy from the national to the EU level, see G Cornelisse, 'Legal Pluralism in the European Regulation of Border Control: Disassembling, Diffusing, and Legalizing the Power to Exclude' in G Davies and M Avbelj (eds), Research Handbook in Legal Pluralism and EU Law (Cheltenham, Edward Elgar Publishing 2018). For a discussion of challenges posed by the 'refugee crisis' and return policies to the EU integration project, see P Vimont, 'The European Project in Crisis: Myths and Realities', in IEMed Mediterranean Yearbook 2017, https://carnegieeurope.eu/2017/11/17/ european-project-in-crisis-myths-and-realities-pub-74770.
} 
answer (section II). Third, we contextualise some of the key findings of the individual chapters as regards the contribution of courts and judicial dialogue to the implementation of the Return Directive, paying specific attention to future challenges of courts and judicial dialogue in return proceedings (section III).

\section{Research Agenda: Why Courts, Why Return, Why Judicial Dialogue?}

More than ten years after the adoption of the Return Directive, an in-depth analysis of the role of courts and judicial dialogue in return proceedings is timely. The Directive is one of the most controversial instruments of EU immigration policy, being one of the longest negotiated, ${ }^{16}$ most criticised ${ }^{17}$ and most litigated instruments of European migration management. ${ }^{18}$ Nonetheless, an instrument that started out as the 'Directive of Shame'19 has in some respects become a normative example for legal orders around the globe ${ }^{20}$ due to its unexpected protective effect for the rights of irregular third-country nationals in practice. It is significant that the 'protective' potential of the Directive has been gradually built by European and national courts, which have acted - often in dialogue with each other - as gatekeepers for the human rights protection of irregular migrants and the effective implementation of the Directive. ${ }^{21}$ Their task has been far from easy,

\footnotetext{
${ }^{16}$ For more details on the negotiation procedure, see F Lutz, The Negotiations on the Return Directive (Nijmegen, Wolf Legal Publishers, 2010).

${ }^{17}$ A Baldaccini, 'The Return and Removal of Irregular Migrants under EU Law: An Analysis of the Returns Directive' (2009) 11 European Journal of Migration and Law 1 (citing international organisations, third countries and other officials criticising the Directive); E Guild, 'Illegal Migrants: Proposals for a Common EU Policy on Returns', 32nd Report of Session 2005-06, 121 (Q384); D Acosta Arcarazo, 'The Returns Directive: Possible Limits and Interpretation' in K Zwaan (ed), The Returns Directive: Central Themes, Problem Issues, and Implementation in Selected Member States (Nijmegen, Wolf Legal Publishers, 2011); V Mitsilegas, The Criminalisation of Migration in Europe: Challenges to Human Rights and the Rule of Law (Springer, London, 2015) 93-107; S Carrera, Implementation of EU Readmission Agreements: Identity Determination Dilemmas and the Blurring of Rights (Springer, London, 2016), 56.

${ }^{18}$ Of all the EU immigration instruments, the Return Directive has been the object of the highest number of preliminary rulings delivered by the CJEU, 30 in a period of 10 years (last checked 31 October 2019).

${ }^{19}$ Or 'a draconian policy towards migrants', see V Mitsilegas, 'Immigration Detention, Risk and Human Rights in the Law of the European Union. Lessons from the Returns Directive' in N Guia, R Koulish and V Mitsilegas (eds), Immigration Detention, Risk and Human Rights (Springer, Cham, 2016) 27.

${ }^{20}$ See the statement of the UN Special Rapporteur on the expulsion of aliens acknowledging that the Return Directive 'contains extremely progressive provisions on such matters that are far more advanced than the norms found in other regions of the world'. in Communication from the Commission to the Council and the European Parliament on the EU Return Policy, Brussels, 28.3.2014 COM(2014) 199 final, 30; MJ Flynn, 'Conclusion: The Many Sides to Challenging Immigration Detention' in MJ Flynn and MB Flynn (eds), Challenging Immigration Detention Academics, Activists and Policy-makers (Cheltenham, Edward Elgar Publishing, 2017).

${ }^{21}$ By 'protective' this book refers to human rights, but also to other rights and procedural safeguards such as legal certainty, transparency, primacy of voluntary departure and good administration.
} 
since it involves striking the right balance between at times competing objectives: effective returns and protection of human rights. Furthermore, as shown by the chapters in this volume, domestic courts have had to overcome constitutional, legislative and executive hurdles limiting judicial intervention and scrutiny of administrative decision-making in matters of immigration. ${ }^{22}$ The Return Directive has thus enabled removal cases to be litigated before courts and empowered domestic judges to exercise a degree of control which they lacked before. However, this nascent reordering of the balance between state powers has been under threat since the 'refugee crisis', with both supranational and domestic courts facing immense pressures from governments in immigration cases. ${ }^{23}$ This book analyses how such challenges have played out in courts' scrutiny of return-related measures.

Moreover, the discourse of crisis and threat ${ }^{24}$ has also led to proposed changes in the legislative framework governing migration and asylum at the European level. In September 2018 the European Commission put forward a proposal for amending the Return Directive. ${ }^{25}$ The Proposal has been criticised for betraying a shift in the EU's immigration agenda by prioritising speedy returns, increasing possibilities for the use of pre-removal detention, and limiting judicial scrutiny, thus overlooking important human rights and procedural guarantees developed by European and domestic courts. ${ }^{26}$ Within this highly charged political context of attempts to curb the powers of national courts in this area (with governments at times even holding courts responsible for the inefficiency of return policy), ${ }^{27}$ it is particularly important to assess the contribution of courts to the implementation of the Directive across the Member States. Now that the value and usefulness of existing legal instruments such as the Return Directive are being debated and changes proposed, taking a closer look at the way in which the

\footnotetext{
${ }^{22}$ For additional constitutional limitations as regards the judicial review of pre-removal detention, see M Moraru and G Renaudiere, REDIAL Research Report 2016/05, available at http://euredial.eu/. More broadly, outside the EU, see M Giannacopoulos, M Marmo and W De Lint, 'Irregular Migration: Emerging Regimes of Power and the Disappearing Human' (2012) 22 Griffith Law Review 559.

${ }^{23}$ See the press releases of Salvini and Orban (n 11). See also the 2017 Minitti Decree limiting the hearing powers of immigration courts in Italy (Decreto-legge 13 of 17 February 2017, see further amendments in Decreto-legge 53 of 14 June 2019); as regards the pressure exercised by governments on the ECtHR, see the Separate Opinion of Judge Alburquerque in MA and others $v$ Lithuania, Appl No 59793/17, Judgment of 11 March 2019, and the Draft Copenhagen Declaration, of 5 February 2018, points 25 and 26.

${ }^{24}$ See the EU's strategic agenda for 2019-2024, European Council, 20-21 June 2019.

${ }^{25}$ See Proposal for a Directive of the European Parliament and of the Council on common standards and procedures in Member States for returning illegally staying third-country nationals (recast) Brussels, 12.9.2018 COM(2018) 634 final 2018/0329 (COD) ('the Proposal').

${ }^{26}$ Such as: the principle of non-refoulement, the right to be heard, priority of voluntary departure, due-diligence obligations. See Opinion from the Fundamental Rights Agency (FRA Opinion - 1/2019 [Return], Vienna, 10 January 2019, 'The recast Return Directive and its fundamental rights implications'; and ECRE Comments on the Commission Proposal for a Recast Return Directive COM(2018) 634, November 2018.

${ }^{27}$ See 2017 EMN Report on the effectiveness of return in the EU Member States, 3.
} 
Directive has been applied by courts in the Member States over the last ten years seems timely and necessary.

While a focus on the role of courts when investigating the implementation of the Return Directive is clearly necessary in light of national and European institutional and political dynamics, the chapters in this volume do not merely address the role of courts. They also use the concept of judicial dialogue to analyse the regulation of irregular migration in Europe and the implications of such regulation for individual rights and institutional settings. A focus on dialogue between judges is warranted for several reasons. First, a very high number of preliminary references have been sent by national courts from both old and new Member States on the Return Directive. ${ }^{28}$ An analysis of the dynamics within domestic judiciaries leading to such references and their subsequent impact on national practice can show under which conditions EU law can lead to shifts in the balance of powers within Member States and within the EU as a whole, and illustrate the extent of the Directive's effectiveness.

Second, the specific characteristics of EU law, such as the decentralised system of implementation relying on national courts (and individuals claiming their rights) for the enforcement of EU law, ${ }^{29}$ the obligation of uniform application of EU law, and differences between the judicial roles of the CJEU and domestic judiciaries, mean that an analysis of the role of courts in implementing the Return Directive needs to be mindful of the wider legal and discursive framework in which that role is carried out. More specifically with regard to the way in which the characteristics of EU law could affect the balance of powers in the area of immigration law enforcement, it is significant that the preliminary reference procedure in Article 267 TFEU may provide domestic courts with opportunities to circumvent domestic courts' hierarchy, as every court in the EU may refer questions to the CJEU. ${ }^{30}$

Finally, judges adjudicating the Return Directive are not only 'ordinary judges of EU law' but act in an area that is increasingly regulated by a multiplicity of legal orders, including the ECHR and global legal norms. Norms emanating from these orders may at times be complementary or mutually reinforcing, or they may be in tension or even conflict with each other. If we want to know more about the judicial role in adjudicating irregular migration and its effects on individual rights and institutional balance, we need to pay close attention to the ways in which courts navigate these different legal orders. Such a perspective inherently requires addressing the question of whether judges from different legal orders

\footnotetext{
${ }^{28}$ eg Belgium, Bulgaria, the Czech Republic, France, Germany, Italy and the Netherlands.

${ }^{29} \mathrm{JHH}$ Weiler, 'Van Gend en Loos: The Individual as Subject and Object and the Dilemma of European Legitimacy' (2014) 12 International Journal of Constitutional Law 94.

${ }^{30} \mathrm{G}$ Cornelisse, 'Immigration Detention: An Instrument in the Fight Against Illegal immigration or a Tool for its Management?' in M Joao Guia, V Mitsilegas and R Koulish (eds), Immigration Detention, Risk and Human Rights (Cham, Springer, 2016) 73, 88. See also A Dyevre, 'Judicial Non-Compliance in a Multi-Level, Nonhierarchical Legal Order: Isolated Accident or Omen of Judicial Armageddon?' [2012] Max Planck Institute for International and Comparative Law.
} 
interact with each other when dealing with complementarity or conflict. Indeed, the perspective of judicial dialogue can elucidate how the judiciary approaches issues such as uniform interpretation, normative clarification and conflict resolution when adjudicating issues that are regulated by a plurality of legal orders, and the implications thereof for the protection of individual rights and increasing scrutiny of executive power.

While the role of courts and judicial dialogue has been the subject of a vast literature covering numerous fields of law and political science, ${ }^{31}$ this book is the first to analyse the implementation of the Return Directive from the perspective of courts and judicial dialogue. Interaction between judges when applying or interpreting the Return Directive has impacted on the vertical and horizontal delimitation of competences in the EU when it comes to migration. This interaction has affected the state's immigration powers, by limiting its coercive powers of removal, the use of pre-removal detention, and criminalisation of illegal entry or stay. In addition, judicial interaction has redefined the relation between law and policy on irregular immigration and the reinstitution of internal border controls, and has had significant effects on individual rights, including the rights of children and their families and procedural guarantees in return procedures.

However, patterns of judicial dialogue differ depending on the type of return-related measure and the Member State. Broadly speaking, at one end of the spectrum are cases where ample opportunities already exist for judicial scrutiny of executive power (either because domestic courts are already endowed with significant powers of judicial control, or because the norms from one legal order provide particularly robust guarantees). In such cases, there is relatively little dialogue between judges. At the other end of the spectrum, where national courts are strongly constrained in exercising control (which can be for a variety of reasons ranging from traditional, deeply entrenched views on the judicial role to more prosaic constraints such as time limits), dialogue is also much less likely to flourish. Accordingly, most dialogue is seen in the cases that sit between these two poles. In these cases, the interaction between judges has opened up space for contestation of domestic immigration law and changes in institutional configurations. In section III we will present the main findings of the book on the outcomes of judicial dialogue and discuss challenges to its future development. Before doing so, we explain what we understand by the term judicial dialogue and set out the research design of this book.

\footnotetext{
${ }^{31}$ AM Slaughter, 'A Global Community of Courts' (2003) 44 Harvard International Law Journal 191; by the same author, A New World Order (Princeton, NJ, Princeton University Press, 2004); D Baldinger, Vertical Judicial Dialogues in Asylum Cases: Standards on Judicial Scrutiny and Evidence in International and European Asylum Law (Leiden, Brill, 2015); A Müller, Judicial Dialogue and Human Rights (Cambridge, Cambridge University Press 2017); P Lobba and T Mariniello, Judicial Dialogue on Human Rights: The Practice of International Criminal Tribunals (Leiden, Brill, 2017); B de Witte, JA Mayoral, U Jaremba, M Wind and K Podstawa, National Courts and EU Law, New Issues, Theories and Methods (Cheltenham, Edward Elgar Publishing, 2016).
} 


\section{Research Design: What Do We Mean When We Talk About 'Judicial Dialogue'?}

In the last decade, judicial interactions among national and European judges have significantly increased. ${ }^{32}$ Whether direct (eg preliminary reference), indirect (eg citation of European or foreign judgments), informal (eg meetings between national judges, circulation of legal enquiries or questionnaires on the application of certain EU legal provisions), they have contributed immensely to the implementation of EU law. The added value of these interactions is to offer an opportunity to national judges to discuss the development of jurisprudence, tackling problems of interpretation and application in diverse areas of law. Consequently, several disciplines have attempted to develop a general theory of judicial dialogue. ${ }^{33}$

In academic writing, the term 'judicial dialogue' has been given various meanings and qualifications, such as a vehicle for transplants of legal reasoning; ${ }^{34}$ an informal way of communication between judicial and political bodies; ${ }^{35}$ a new paradigm of judicial relations between actors of different legal orders; ${ }^{36}$ a source of communication in which common solutions are built by courts in non-formalised institutional contexts; ${ }^{37}$ ongoing exchange of arguments in order to reach common understandings; $; 8$ exchange of arguments for the purpose of achieving a specific outcome; ${ }^{39}$ and mutual references to case-law, including cross-citation leading to positive impact as well as to debate or opposite judicial solutions. ${ }^{40}$

\footnotetext{
${ }^{32}$ Anne-Marie Slaughter suggested that courts and other quasi-judicial bodies are increasingly entering into a dialogue among themselves (see 'A Global Community of Courts' (n 31)); see also the other authors cited in $\mathrm{n} 31$.

${ }^{33}$ For a legal perspective, see, among others, Slaughter, 'A Global Community of Courts' (n 31) 191; AT Pérez, Conflicts of Rights in the European Union: A Theory of Supranational Adjudication (Oxford, Oxford University Press, 2009) ch 5; A Arnull, 'Judicial Dialogue in the European Union' in J Dickson and P Eleftheriadis (eds), Philosophical Foundations of European Union Law (Oxford, Oxford University Press, 2012); for a political science perspective, see E Voeten, 'Borrowing and Nonborrowing among International Courts' (2010) 39 Journal of Legal Studies 547; U Sadl and Y Panagis, 'The Force of EU Case Law: An Empirical Study of Precedential Constraint' (JURIX Proceedings, Foundation for Legal Knowledge Based Systems, 2015); U Sadl and H Palmer, 'Can Quantitative Methods Complement Doctrinal Legal Studies? Using Citation Network and Corpus Linguistic Analysis to Understand International Courts' (2017) 30 Leiden Journal of International Law 327.

${ }^{34}$ EF Mac-Gregor, 'What Do We Mean When We Talk about Judicial Dialogue: Reflections of a Judge of the Inter-American Court of Human Rights' (2017) 30 Harvard Human Rights Journal 89.

${ }^{35}$ In particular in the US literature, see eg MC Miller, Exploring Judicial Politics (Oxford, Oxford University Press 2009).

${ }^{36}$ Arnull (n 33) 133; A Rosas, 'The European Court of Justice in Context: Forms and Patterns of Judicial Dialogue' (2007) 1 European Journal of Legal Studies.

${ }^{37} \mathrm{M}$ Claes and M de Visser, 'Are You Networked Yet? On Dialogues in European Judicial Networks' (2012) 8(2) Utrecht Law Review 100; D Sarmiento, 'The Silent Lamb and the Deaf Wolves. Discursive Pluralism, Preliminary References and Empty Judgments in a Brave New World', paper presented at the conference 'Constitutional Pluralism in the EU and Beyond', Oxford, 20-21 March 2009.

${ }^{38}$ See Pérez (n 33) 112-13.

${ }^{39}$ LB Tremblay, 'The Legitimacy of Judicial Review: The Limits of Dialogue between Courts and Legislatures' (2005) 3(4) International Journal of Constitutional Law 617.

${ }^{40}$ European Commission, Democracy through Law (The Venice Commission), 'Report on the Implementation of International Human Rights Treaties in Domestic Law and the Role of Courts' (8 December 2014).
} 
Other scholars have defined judicial dialogue by its purposes and effects rather than by its characteristics. Those purposes and effects purportedly lie in enhancing the effectiveness, persuasiveness and legitimacy of supranational law through the creation of a process of collective deliberation, cross-fertilisation of case-law and domestication of international obligations. ${ }^{41}$ Several scholars argue that for a robust dialogue to develop, several prerequisites have to be fulfilled, of which reciprocity and mutual recognition, respect between the actors engaging in dialogue, and continuity over time are key features. ${ }^{42}$ A closer look reveals that legal scholars habitually adopt three meanings of judicial dialogue. They employ a narrow understanding when judicial dialogue would require reciprocity between the courts engaged in dialogue. ${ }^{43} \mathrm{~A}$ broader sense of judicial dialogue can be seen when it is defined as a set of various interactions among courts, which do not necessarily involve reciprocity and continuity over time. ${ }^{44}$ A last, broadest understanding of judicial dialogue not only looks at formal judicial interactions, but also includes informal communications among judges outside the courtroom. ${ }^{45}$ This book uses the second meaning of judicial dialogue as the use of judicial reasoning from one court by another court, for the purpose of constructing a better interpretation of a legal norm, without necessarily involving reciprocity or continuity over time.

In this book, then, judicial dialogue refers to the various techniques that courts and judges resort to in order to solve issues of normative or judicial interpretation incompatibility in a way that ensures coherence and coordination among different judicial systems in the safeguard of effectiveness of EU law and legal obligations stemming from other legal orders (including but not limited to European and global human rights law). Judicial interactions may differ from each other in intensity, outcome and typology. Notably, within the EU there can be a dialogue along three dimensions. First, judicial interactions habitually occur between national judges and the CJEU, most notably in the preliminary reference procedure, but also when national judges engage in other ways with CJEU case-law. This we call vertical judicial dialogue. This term we use also for engagement by national judiciaries with ECtHR case-law. Second, there will often be interactions between judges within the same Member State, which we call horizontal judicial dialogue. Third, national judges may engage with the case-law of other Member States' courts, which we call transnational judicial dialogue. The term transnational judicial dialogue can also describe interactions between the CJEU and the ECtHR. As we employ a broad understanding of the concept, judicial dialogue can take various forms, of which the most important are the duty of consistent interpretation of national law with EU legal obligations as interpreted by the CJEU; the preliminary reference

\footnotetext{
${ }^{41}$ AM Slaughter, 'A Typology of Transjudicial Communication' (1994) 29 University of Richmond Law Review 99.

${ }^{42}$ See, in particular, Pérez (n 33); Slaughter, 'A Global Community of Courts' (n 31).

${ }^{43}$ Pérez, Slaughter, ibid.

${ }^{44}$ MacGregor (n 33).

${ }^{45}$ Claes and de Visser (n 37).
} 
procedure; mutual recognition of foreign judgments; comparative reasoning with national legislation and jurisprudence from other Member States; disapplication of national law due to violation of EU law as explained by the CJEU; and engagement with judgements from the ECtHR by national judiciaries. ${ }^{46}$

The premise of this book is that judicial dialogue can answer complex legal questions relating to the implementation of the Return Directive. Throughout its chapters, the book will analyse the impact of various forms of judicial dialogue on return procedures, and take stock of the effect on the rights of the returnees and the institutional configuration within the Member States and the EU when it comes to regulating migration control. Three overarching questions accordingly guide the assessment of judicial dialogue in this volume. First, has judicial dialogue contributed to a more coherent application of the Return Directive across Europe, or has it resulted in an even more complex legal situation than before such dialogue took place? Second, can judicial dialogue resolve the tension between the requirements of the Directive and the legal and institutional configuration regulating immigration powers in the Member States, and under which conditions is this so? Third, have judicial interactions enhanced the protection of the fundamental rights of individuals, and if so, in what way?

To comprehensively address these questions, the book brings together leading authors from various backgrounds, including scholars, lawyers, judges and policy officers. ${ }^{47}$ This allows the collection to offer both theoretical and practical perspectives on the relationship between judicial dialogue and the implementation of the Return Directive. Jurisprudence by courts from all levels of jurisdiction is covered and has been primarily collected within the Return Directive DIALogue (REDIAL) Project. ${ }^{48}$ An additional innovative contribution of the book to the field of immigration governance is that of engaging the actual protagonists of judicial dialogue - judges - in the research design. While writing their chapters, all contributors were invited to consider a common list of questions, such as: which types of judicial dialogue were used to solve a conflict or unclarity regarding the implementation of the Return Directive? Are there preferences for a certain type of judicial dialogue within particular states? What are the reasons for not using judicial dialogue? What challenges do judges face in using judicial dialogue? And what is the impact of judicial dialogue on national case-law, legislation and administrative practice ${ }^{49}$ In the next section we will present the

\footnotetext{
${ }^{46}$ For a more in-depth analysis of 'Judicial Interaction Techniques', see M Moraru, 2017 ACTIONES Module of Judicial Interaction Techniques, published by the Centre for Judicial Cooperation of the European University Institute, available on the website of the CJC, see https://cjc.eui.eu/wp-content/ uploads/2019/03/D1.1.b-Module-2.pdf.

${ }^{47}$ Seventeen scholars and 11 practitioners (judges, lawyers and policy officers) have contributed to this book. For more details on the REDIAL Project, see http://euredial.eu/.

${ }^{48}$ The jurisprudence is included in the REDIAL database and is analysed in the National Reports, European Synthesis Reports and Electronic Journals, available http://euredial.eu/.

${ }^{49}$ The jurisprudence analysed by the authors consists primarily of that collected within the REDIAL database and analysed in the National Reports, European Synthesis Reports and Electronic Journals, available at http://euredial.eu/.
} 
key findings of the individual chapters, relating them to the three overarching research questions.

\section{The Return Directive and Judicial Dialogue: Is the Genie Out of the Bottle?}

This volume is divided into three parts, dealing with termination of illegal stay (Part I), pre-removal detention (Part II) and procedural safeguards (Part III). These correspond largely to the structure of the Return Directive which starts out with a chapter on general provisions, moves on to the procedure to be followed in the case of illegal stay, then deals with procedural safeguards and contains a separate chapter on the use of detention in removal procedures. In this section we briefly present the three parts and their individual chapters, contextualising their key findings against the overarching themes: to what extent has judicial dialogue on the implementation of the Directive brought more coherence and uniformity with regard to return procedures within Europe, and how has it impacted the rights of irregular migrants and affected the institutional balance within the EU and the Member States?

The aim of Part I is to offer a comparative overview of the contribution of courts and judicial dialogue to the scope of application of the Return Directive and the order of measures to be followed by administrative authorities in return proceedings. Perhaps one of the most difficult tasks of domestic courts in the implementation of the Return Directive is the determination of the Directive's scope of application when other legal fields are partially overlapping, such as EU legal migration, asylum, citizenship and/or domestic criminal law. ${ }^{50}$ For instance, in Chapter 1, Galina Cornelisse analyses courts' contributions in resisting the persistent attempts of governments to withdraw immigration proceedings from the scope of the Return Directive into that of domestic law. She argues that the vertical judicial dialogue started by domestic courts from different Member States has led to a process of creeping competences of the EU over immigration which is an inevitable, although at times unintended, result of procedural harmonisation; and which will not stop soon. Judicial dialogue on the vertical delimitation of competences arguably resembles a snowball, with one preliminary question paving the way for the next, implicating ever more areas of European regulation, and leaving ever fewer issues within the sole discretion of the Member States.

The next challenge in the implementation of the Return Directive has been the determination of the order of return-related measures. Again, vertical judicial

\footnotetext{
${ }^{50}$ Since the entry into force of the Return Directive, the scope of application of the Directive has been the persistent object of preliminary questions addressed to the CJEU, starting with Arslan (Case C-534/11 ECLI:EU:C:2013:343) and continuing with most recent $M A$ and others (Case C-673/19 registered on 11 September 2019), see more in G Cornelisse, 'The Scope of the Return Directive: How Much Space Is Left for National Procedural Law on Irregular Migration?, Chapter 1 in this volume.
} 
dialogue has clarified the guiding principle of return proceedings - that is, the sliding scale of measures according to which the Member States should first issue a return decision, ${ }^{51}$ then consider allowing a period for voluntary departure, ${ }^{52}$ and only if this is not possible to proceed with removal. The subsequent chapters in Part I analyse the processes of judicial dialogue leading up to the now settled principle of 'gradualism' dictating the choice of the appropriate return measure. ${ }^{53}$

First, the challenges of making a return decision the first step of a return procedure are analysed by Cristina J Gortázar Rotaeche, in particular within Spain. Chapter 2 shows that vertical judicial dialogue might not immediately lead to the systemic reform of a domestic expulsion system (in the case of Spain, to issuing a return decision instead of imposing financial penalties). Her chapter shows that even when judicial dialogue is used, its domestic effects need time to develop uniformly. Unclear transposition may contribute to this lagging, especially when the legislature uses terms and notions in implementing legislation that have established connotations in prior administrative practice. ${ }^{54}$

The next stage in the return procedure is the voluntary departure measure. In Chapter 3, Ulrike Brandl shows how judicial dialogue has been significant in clarifying key guarantees in the implementation of voluntary departures, such as pertaining to the starting point of the period for voluntary return, circumstances where extension of the voluntary departure period is necessary and the importance of hearing irregular third-country nationals before deciding whether to grant voluntary departure. The concept of voluntary return and the judicial dialogue it spurred provide a particularly apt example of how legal norms formulated at the EU level have been able to open space for contestation by turning the human interests of irregular migrants into rights that are justiciable and enforceable by domestic courts, a dynamic exemplified by the CJEU judgment in $\mathrm{Zh}$ and $\mathrm{O} .{ }^{55}$

In Chapter 4, Aniel Pahladsingh analyses the legal requirements of the entry ban set out in the Return Directive and the role of vertical judicial dialogue in clarifying their application. He argues that vertical judicial dialogue filled the gaps left by EU legislation or eliminated incompatibilities between national legislation and provisions of the Return Directive, by bringing in fundamental rights such as respect for private and family life (Article 7 Charter) and the best interests of the

\footnotetext{
${ }^{51}$ Art 6 of the Return Directive.

${ }^{52}$ Art 7 of the Return Directive.

${ }^{53}$ The term 'gradualism' is expressly mentioned by the CJEU in Case C-61/11 PPU El Dridi ECLI:EU:C:2011:268, para 41.

${ }^{54}$ This conclusion as regards the Member States' lagging behind the reform of their return procedure according to the principle of gradualism and prioritisation of voluntary departure can be found also in some of the chapters in Part II, eg A Di Pascale, 'Can a Justice of the Peace Be a Good Detention Judge? The Case of Italy', Chapter 13 in this volume; S Slama, 'Trois hautes juridictions nationales pour une directive: une interaction judiciaire en trompe l'œil', Chapter 14 in this volume; and S Sarolea, 'Detention of Migrants in Belgium and the Criminal Judge: A Lewis Carroll World', Chapter 11 in this volume.

${ }^{55}$ Case C-554/13 Zh and O ECLI:EU:C:2015:377.
} 
child (Article 24(2) Charter). He shows that in the Netherlands, horizontal judicial dialogue has also played a crucial role in diffusing legal uniformity domestically regarding issues such as the grounds for an entry ban or the definition of serious threat to public security and national security, but argues that more effort is needed by way of national courts playing a more active role in improving the quality, effectiveness and uniform application of EU legislation.

The mixed story of successes and failures of judicial dialogue continues in Chapter 5, which analyses the implementation of one of the most problematic notions introduced by the Return Directive: 'the risk of absconding. ${ }^{56}$ Madalina Moraru shows how national courts have used judicial dialogue (vertical, transnational and horizontal) to unveil the meaning of the risk of absconding in an attempt to determine the correct return measure to adopt when such a risk is present. Indirectly, the unfolded judicial dialogue has succeeded in strengthening courts' position vis-a-vis domestic administrative authorities in an attempt to ensure the effet utile of the Return Directive. While judicial dialogue has widely contributed to the legality and transparency of objective criteria (ie definition in national legislation), the number and content of objective criteria have mostly remained as before the entry into force of the Directive. On this issue, the intervention of courts has been quite conservative and did not lead to a systemic reform of the long domestic lists of objective criteria along the lines of the CJEU jurisprudence.

While the first five chapters identify multidimensional instances of judicial dialogue, and indicate an overall positive impact on the effective enforcement of Return Directive, fundamental rights protection and procedural safeguards for irregularly present third-country nationals, Chapter 6 illustrates how a particular legal-political context can severely limit the possibilities for judicial dialogue to develop. Corina Demetriou and Nicos Trimikliniotis highlight the critical role of the Cypriot courts in ensuring (or undermining) effective implementation and engaging with gaps and weaknesses in the outcomes. They argue that the problems encountered in accessing rights under the Directive partly stem from the failure of the domestic judicial tradition to learn from European and foreign courts and to embrace a rights-based approach. Mostly, however, these problems arise from flaws in the Cypriot judicial system itself. The reluctance to afford primacy to the protection of fundamental rights as enshrined in the Charter, and to interpret all laws transposing the EU acquis in a manner compliant with the Charter, remains a key issue for Cypriot courts. In most cases, the (incorrect and partial) transposition of the Return Directive has brought little change to administrative policies and practices, and to judicial approaches.

The chapters of Part I show that judicial dialogue has triggered a process of reform of domestic expulsion procedures, requiring a change of notions, definitions, chronological order of return measures, and, most importantly, of their 'securitisation' or 'criminalisation' approaches for managing irregular migration.

\footnotetext{
${ }^{56}$ The risk of absconding is defined in Art 3(7) of the Return Directive.
} 
Nevertheless, the process of reform requires more sustained efforts, first to ensure that the application of the Return Directive becomes the norm, instead of circumventing its application by recourse to criminal sanctions for return related offences, and second to prioritise voluntary departure instead of removal and entry bans.

Part II of the volume addresses judicial dialogue on pre-removal detention under the Return Directive. The norm of judicial control of a deprivation of personal liberty was part of the constitutional traditions of the Member States, international human rights law including the ECHR, and the Charter long before it was codified in Article 15 of the Return Directive. Moreover, in contrast to other human rights, the procedural guarantee of judicial control forms an inherent part of the right to personal liberty itself. ${ }^{57}$ Theoretically, then, the robust guarantee of judicial control when it comes to any deprivation of personal liberty stands in stark contrast to the traditional deference shown to the executive in matters of immigration. The conflicting forces which accordingly regulate the role of the judiciary when deciding on immigration detention, taken together with the multiplicity of legal instruments that require their intervention, turn pre-removal detention into a particularly apt case study for analysing the role of judges in implementing the Return Directive, and their use of judicial dialogue when doing so. The chapters in this part of the book show that the Return Directive has generally led to increased protection of the rights of detained irregular immigrants, for example through a stronger insistence on the use of alternative measures. ${ }^{58}$ Moreover, judicial dialogue on the scope of judicial review under Article 15 of the Return Directive has empowered (or required) courts in the Member States to extend their powers significantly vis-a-vis administrative discretion. However, the chapters also show the limitations of judicial dialogue and courts' intervention, which have not fully succeeded in fundamentally reforming domestic return systems that rely on pre-removal detention as a normalised part of return procedures.

Part II starts with two chapters that provide a solid basis for understanding the impact of courts and judicial dialogue on pre-removal detention. In Chapter 7, Lilian Tsourdi analyses how alternatives to immigration detention have featured in diverse legal regimes in order to uphold the prohibition of arbitrary deprivations of liberty. She does so by engaging with decisions by the UN Human Rights Committee and judgments by the ECtHR and the CJEU on immigration detention, and explores how these bodies have interacted with each other. The chapter shows that specific instruments of EU law and the case-law of the CJEU

\footnotetext{
${ }^{57}$ See, amongst many examples in all major human rights documents, Art 5(4) ECHR and Article 9(3) ICCPR.

${ }^{58}$ See, in particular, I Jarukaitis and A Kalinauskaite, 'The Administrative Judge as a Detention Judge: The Case of Lithuania, Chapter 9 in this volume; A Di Pascale, Can a Justice of Peace Be a Good Detention Judge? The Case of Italy', Chapter 12 in this volume; and S Slama, 'Trois hautes juridictions nationales pour une directive: une interaction judiciaire en trompe l'œeil', Chapter 14 in this volume.
} 
have paved the way for a more stringent requirement that immigration detention always be a proportionate measure. Tsourdi also highlights an instance of transnational judicial dialogue gone awry: the selective reading by the CJEU of the ECtHR case-law when public order prerogatives and immigration detention interact. ${ }^{59}$ Next, Chapter 8 zooms in on national models of judicial scrutiny of detention, with a particular focus on the relationship between institutional design and scope of review. David Kosar and Adam Blisa expose significant institutional diversity in the domestic design of judicial review of detention under the Return Directive. This diversity exemplifies the fact that while the procedural requirement of judicial control of detention has been part of the constitutional tradition of individual Member States, the historical development of the judiciary and its position versus the executive has followed vastly differing trajectories in the Member States. Kosar and Blisa show that differing institutional setups across the EU have substantial impact on the quality of the control of pre-removal detention. They identify relevant factors in reducing what they call the detention roulette'.

Part II continues with six chapters that further detail the legal and institutional framework of judicial control of pre-removal detention by focusing on its main models and their implications for judicial dialogue. Chapter 9 analyses the German model, where the transposition of the Return Directive affirmed the central role accorded by the German Constitution to the civil judge as the principal administrator of pre-removal detention. Jonas Bornemann and Harald Dörig show that the constitutional requirement of full review of the legality of detention means that German civil judges are not inclined to engage in judicial dialogue in this area. Nonetheless, they identify a crucial instance of vertical judicial dialogue on the implementation of return detention in prisons, which resulted in a significant decline in detention orders, thereby illustrating the receptivity of the German model to additional safeguards from other legal orders, if required. Chapter 10 examines the role of administrative judges in Lithuania in reviewing pre-removal detention. Irmantas Jarukaitis and Agnè Kalinauskaite note that in contrast to other areas of law, vertical judicial dialogue on pre-removal detention is limited. They argue that this may be the result of a trade-off between the requirement of a speedy judicial review of any deprivation of liberty, and the completeness of legal reasoning in the sense of reliance on EU law. Importantly, the authors remind us that judicial dialogue is not an end in itself: just as in Germany, in Lithuania its use may be limited because full powers of review are already exercised as a result of domestic legal requirements.

The remaining chapters in Part II reveal more problematic systems of judicial control of detention, when assessed against checks on the exercise of executive power and the protection of individual rights. In Chapter 11, Sylvie Sarolea argues that the Belgian model, where a criminal judge reviews pre-removal detention, is

\footnotetext{
${ }^{59}$ Case C-601/15 PPU JN ECLI:EU:C:2016:84.
} 
fundamentally flawed because criminal judges have limited power to review the legality of return and removal, resulting in ineffective review of detention. Her contribution draws attention to the absence of horizontal and vertical judicial dialogue when judges control the lawfulness of pre-removal detention, ${ }^{60}$ caused by a particular institutional setup upon which the Return Directive has had surprisingly little impact. Similarly, in Chapter 12, Angeliki Papapanagiotou-Leza and Stergios Kofinis highlight constraints inherent in the legal remedy provided for by Greek legislation, to explain the lack of direct vertical and transnational judicial dialogue on pre-removal detention. They draw attention to the limited opportunities for judicial reasoning, the absence of specific procedural rules, and the lack of second-level jurisdiction in detention cases. In Chapter 13, Alessia Di Pascale assesses a particular model of judicial control, exercised by justices of the peace. She argues that the attribution of jurisdiction to the justice of the peace has not provided an opportunity for careful control of the lawfulness of detention, nor for vertical judicial dialogue, a situation which may be partially remedied through the engagement of the Italian Court of Cassation. Part II concludes with a controversial story of intricate instrumentalisation of judicial dialogue. In Chapter 14, Serge Slama argues that when it comes to reviewing detention, French courts conduct a judicial interaction 'a trompe l'oeil': an instrumental use of judicial dialogue between themselves and with the CJEU. The aim is, essentially, to protect the domestic courts' margin of appreciation and those of the administration, without necessarily ensuring the effectiveness of return procedures or protecting the fundamental rights of third-country nationals. ${ }^{61}$

Part III of the volume assess the judicial implementation of procedural safeguards and rights of irregularly present third-country nationals throughout the various stages of return procedures, touching in particular on the provisions of Chapter III of the Return Directive. These provisions allow a substantial margin of discretion to the Member States, which the authors argue has been shaped by courts and judicial dialogue in prominent judgments. A common thread in this part is the crucial role played by the Charter, the ECHR and general principles of EU law in gap-filling on procedural safeguards in return procedures at both EU and domestic levels, and as legality parameters for national legislation on access to social benefits pending removal. Reading these chapters, it becomes evident that return proceedings are, in practice, closely linked to other migrationrelated proceedings, such as asylum or visa/residence procedures. Therefore, as

\footnotetext{
${ }^{60}$ It is important to highlight that other areas relating to the rights of irregularly staying third-country nationals may be much less characterised by the absence of judicial dialogue. Thus, the case-law of the CJEU on the right to be heard has led to significant developments in the jurisprudence of Belgian courts. For instance, the Council of Alien Law Litigation (CALL) now consistently applies the right to be heard as a general principle of EU law, which has also substantially affected administrative practice. See M Moraru and G Renaudiere, 'European Synthesis Report on the Judicial Implementation of Chapter III of the Return Directive Procedural Safeguards' REDIAL Research Report 2016/03, 12.

${ }^{61}$ Here a similar qualification should be made as with regard to the situation in Belgium; especially salient in this respect is that judicial dialogue on the right to be heard originated in France.
} 
mentioned in Part I, a return judge must have a proper understanding of other migration-related issues and procedures in order to deliver a just judgment. This conclusion takes shape in the first chapter of Part III, where Valeria Ilareva shows how the right to be heard in return procedures is closely linked to the right to be heard in asylum and other migration-related procedures, and how deciding on the right to be heard in one of these procedures has implications for the right to be heard in return procedures. She also argues that while other EU migration provisions regulate in more detail the right to be heard of third-country nationals, the right to be heard in return procedures is primarily a court- and judicial-dialoguedriven construct. Analysis of the case-law reveals the potential judicial dialogue has in forging effective standards that correspond to the practical issues arising in the implementation of the right to be heard.

Equally important is the right to an effective remedy. Unlike with the right to be heard, the Directive includes express standards on the right to an effective remedy. Nevertheless, practice has shown the need for further clarification of these standards. In Chapter 16, Boštjan Zalar shows the multiple contributions of judicial dialogue leading to the enhancement of the right to an effective remedy, as enshrined in Article 13 of the Return Directive. After an in-depth analysis of the preliminary questions addressed by domestic courts on the right to effective remedy in return procedures and the answers given by the CJEU, the author claims that the preliminary reference procedure, although it plays an essential role for judicial dialogue between courts of Member States and the CJEU, needs to be complemented by alternative modes of judicial dialogue, as potential means for enhancing the rule of law in relation to the Return Directive. Such alternative judicial dialogues would need to be meaningfully integrated in the knowledgemanagement and quality-management systems of national judiciaries.

Both the right to be heard and the right to an effective remedy have been increasingly limited in circumstances of national security. In Chapter 17, Jacek Białas shows such an example of intrusive limitations pursued by Polish law, which provides that in return cases involving national security, the third-country national has no access to the classified case files and the justification of the decision is limited. His chapter analyses the litigation strategies pursued by lawyers for the purpose of triggering legislative reform ensuring the application of the Return Directive and CJEU standards. Unfortunately, most of these strategies have remained unsuccessful due to the Polish administrative courts' reluctance to use the relevant ECtHR or CJEU case-law or engage in judicial dialogue.

The next chapter focuses on the role of courts and judicial dialogue regarding the rights of children in return procedures (Chapter 18). Carolus Grütters comparatively analyses the contribution of the European and domestic judiciaries to the enhancement of the rights of children. First, he argues that, so far, judicial dialogue on the rights of children in return procedures has concentrated on: (a) detention of children as a last resort; and (b) detention conditions of children. Second, he argues that unlike other provisions of the Return Directive, the rights of children have so far been advanced mostly by the ECtHR, which has increasingly developed 
child-friendly judgments. While judicial dialogue is in an incipient stage on the rights of children in return proceedings, the ECtHR case-law might, nevertheless, affect CJEU jurisprudence in the future.

While the Return Directive prescribes clear steps to be followed in the return procedure, it also acknowledges there might be circumstances were the removal of irregular third-country nationals may or must be postponed for technical or legal reasons. In Chapter 19, Jean-Baptiste Farcy addresses legal impediments to removal as well as the rights of third-country nationals whose removal is postponed. The analysis shows that the case-law of the CJEU regarding 'postponement of removal' and that of the ECtHR have led to congruent judicial standards, in particular with respect to the principle of non-refoulement. However, these courts have yet to engage in a mutual dialogue on the issue of safeguards pending return. While the CJEU gave an extensive reading of the Return Directive's provisions on safeguards pending return, the ECtHR does not offer meaningful remedies to unremovable migrants who may be left in a state of rightlessness. As a result, the status and rights of third-country nationals whose removal is postponed are regulated at national level. Considering the diversity of Member States' practices, the chapter argues that judicial interactions between domestic courts could play a positive role in fostering a shift towards the judicialisation of regularisation. Regularisation would then be based on judicial standards rather than administrative discretion.

The book concludes with Chapter 20, dealing with one of the most politically sensitive issues in return proceedings and more generally immigration - the prohibition of collective expulsion. Jean-Yves Carlier and Luc Leboeuf start from the observation that the prohibition of collective expulsion as interpreted by the ECtHR has not instigated major developments or controversies before the CJEU and domestic courts so far. They reflect on the potential reasons why there does not seem to be a vivid judicial dialogue on the interpretation of that prohibition. They argue that its absence can be explained by the constitutive elements of a collective expulsion as established by the ECtHR, which may be contained already in other provisions established in EU law. They show that the prohibition of collective expulsion evolved from the prohibition of discriminatory policies targeting a given group of aliens on the basis of ethnic criteria, to a broader procedural protection requiring the examination of each individual's situation prior to removal. This requirement is then compared to existing guarantees under EU asylum and migration law, which contains numerous similar procedural and substantive protections requiring the assessment of the situation of each third-country national.

Taken together, the chapters show that formulating clear and unambiguous answers to our research questions is far from easy. Indeed, focusing on the main findings risks not doing justice to the individual chapters, which each in their own way illustrate complexity and instances of judicial conflict, occasional incoherence and disagreement. Our concluding remarks attempt to reconcile the need for clear conclusions on the role of the judiciary in the implementation of the Return Directive, with the equally important requirement of doing justice to the picture 
of nuance and even incoherence, ineffectiveness and conflict that the chapters have brought forward.

First, judicial dialogue has doubtless provided the judiciary in the Member States with more opportunities to control administrative decision-making, thus ensuring the rule of law. Such dialogue has also led to a beneficial exchange of views among judicial authorities, resulting in more elaborate or progressive judicial reasoning. Second, judicial dialogue on the Return Directive has led to enhanced protection of fundamental rights and provided a counterbalance to restrictive or criminalisation approaches advanced by national administrations. As such, judicial dialogue has offered judges opportunities to resist the securitisation paradigm (with its accompanying threats to the rule of law), which has increasingly dictated policy choices made at Member State and EU level in immigration governance. ${ }^{62}$ Third, by filling gaps in European legislation, judicial dialogue has led to a more coherent application of the Directive across the Member States, which has been coupled with an extension of EU competences on irregular immigration.

These three key findings need to be contextualised against three other significant threads emerging from the chapters. The first thread is that judicial dialogue has developed unevenly across the Member States. While in many of these, national courts have started to engage in an extensive and careful dialogue, either directly with the CJEU or indirectly by applying preliminary rulings, or with other courts abroad, in other states the judiciary has been reticent to partake in such dialogue. At times this can be explained by the argument that judicial dialogue is not an aim in itself: if effective protection already exists at the national level, for example because domestic courts have traditionally been endowed with significant powers of review, or if effective implementation of the Return Directive is ensured by other means, then the need for dialogue diminishes. Moreover, a lack of explicit references can also be due to judicial economy considerations: the interpretation provided in CJEU preliminary rulings might be followed without citing the relevant case-law. More often, however, the lack of dialogue has more insidious causes, such as an inward-looking judiciary or a judiciary constrained by institutional or procedural limitations. Even the reactions of referring courts to preliminary rulings by the CJEU have differed: some have readily set aside conflicting national legislation (eg Italian courts following the El Dridi judgment), while others take more time to implement a preliminary ruling (eg Spain, post-Zaizoune). Moreover, transnational judicial dialogue seems to be still in its infancy, with courts showing limited interaction with domestic courts from other Member States. This is unfortunate,

\footnotetext{
${ }^{62}$ See S Carrera, A den Hertog, M Panizzon and D Kostakopoulou (eds), EU External Migration Policies in an Era of Global Mobilities: Intersecting Policy Universes (Leiden, Brill, 2019); S Carrera, 'An Appraisal of the European Commission of Crisis: Has the Juncker Commission Delivered a New Start for EU Justice and Home Affairs?', CEPS paper (2018). On how the Proposal to recast the Return Directive prioritises speedy returns over humane return standards, see J Kilpatrick, 'The Revised Returns Directive: A Dangerous Attempt to Step Up Deportations by Restricting Rights', Statewatch Analysis (September 2019); and FRA Opinion - 1/2019 [Return] (n 26).
} 
as such dialogue can illustrate the need for vertical judicial dialogue, seeing that diverging interpretations of EU law across the Member States ultimately require the engagement of the CJEU.

A second thread is that judicial dialogue, even when used, does not necessarily bring about effective changes or guarantee the uniform application of EU law. This lack of effet utile of judicial dialogue can be explained by courts using it instrumentally, for example to protect the prerogatives of the administration as they have traditionally done, or by viscous institutional settings and legal-political configurations that need time and effort to change. Moreover, the enforcement of domestic or European judgments depends on the effective collaboration of the other branches of state powers. The legislature might delay amendment or incorrectly implement the outcomes of judicial dialogue; the executive might delay the revision of its return-related practices or restrictively interpret judgments favourable to irregular third-country nationals. Ten years after the entry into force of the Return Directive, incorrect implementation is still widespread across the EU. In some instances only a systemic reform of return procedures would bring domestic immigration law into conformity with the Directive and the rule of law.

A third thread is that judicial dialogue has led, to a certain extent, to increased (administrative) complexity in return procedures. ${ }^{63}$ This is partly caused by the plurality of legal orders regulating return and removal and intersection with other legal fields. Instances of conflicting interpretations of legal obligations at the EU level and the ECHR are emblematic for this increasing complexity. These legal and jurisprudential overcomplexities make the task of national judges by far the most difficult among the European judiciaries, as they have to manoeuvre all legal orders when deciding in concrete cases. While judicial dialogue in turn could also help national judges to carry out this complex task, its use in practice is fragmented and certain forms remain minimal. Moreover, as argued by Bostjan Zalar, the academic expectations of judicial dialogue might have been overly optimistic by failing to take account of the professional environment in which judges function. Judicial dialogue, in all its forms and dimensions,

will continue to be limited as long as leading actors within judicial systems do not comprehend that the quality of judicial services is a complex matter that cannot be dealt with simply by monitoring the numbers of judgments upheld or quashed in appeal procedures, and that complex models of quality management must be incorporated into all major aspects of regulation of selection, promotion, evaluation, disciplinary procedure and tenure. ${ }^{64}$

Finally, it is worth reflecting on the future of judicial dialogue in return proceedings and the possible impact on the interpretation of immigration rules in the

\footnotetext{
${ }^{63}$ See more in G Cornelisse, 'The Scope of the Return Directive: How Much Space Is left for National Procedural Law on Irregular Migration?', Chapter 1 in this volume.

${ }^{64}$ See B Zalar, 'Impact of Judicial Dialogue(s) on Development and Affirmation of the Right to Effective Legal Remedy from Articles 13 and 14 of the Return Directive', Chapter 16 in this volume.
} 
age of migration control, ${ }^{65}$ expedited returns ${ }^{66}$ and overcomplexity of procedures. Given the increase of actors competent to act and take decisions in return proceedings (eg European Border and Coast Guard Agency ${ }^{67}$ ), coupled with a persistent absence of experienced legal aid lawyers, and states' efforts to avoid the application of the Return Directive and criticising, at times even curbing, judicial scrutiny powers ${ }^{68}$ the role of courts in preserving the rule of law in return proceedings is set to become ever more difficult. Against this background, judicial dialogue may provide these courts with the critical tools needed to ensure that EU return policy is shaped as it was intended to be from the outset: based on the rule of law, firm but proportionate, humane not hostile. ${ }^{69}$

\footnotetext{
${ }^{65}$ See the Interoperability regulations: Regulation (EU) 2019/817 of the European Parliament and of the Council of 20 May 2019 on establishing a framework for interoperability between EU information systems in the field of borders and visa, and Regulation (EU) 2019/818 of the European Parliament and of the Council of 20 May 2019 on establishing a framework for interoperability between EU information systems in the field of police and judicial cooperation, asylum and migration; see also 'Interoperability and Fundamental Rights Implications - Opinion of the European Union Agency for Fundamental Rights', 11 April 2018, 19.

${ }^{66}$ JP Cassarino, 'Informalizing EU Readmission Policy' in AR Servent and F Trauner (eds), The Routledge Handbook of Justice and Home Affairs Research (London, Routledge, 2018) ch 7; J Slagter, 'An "Informal" Turn in the European Union's Migrant Returns Policy towards Sub-Saharan Africa, MPI Policy Brief (January 2019).

${ }^{67}$ Regulation (EU) 2019/1896 of the European Parliament and of the Council of 13 November 2019 on the European Border and Coast Guard and repealing Regulations (EU) No 1052/2013 and (EU) 2016/1624 PE/33/2019/REV/1 [2019] OJ L295, 1-131.

${ }^{68}$ For example, Art 16(1) of the proposal for the recast Return Directive imposes a single level of jurisdiction against the return decision where it is based on a decision rejecting an asylum application when that decision has already been subject to an effective judicial review according to Art 53 of the (not yet finalised) Asylum Procedure Regulation. Furthermore, a very tight deadline was proposed by the EC for appealing before a court (see Proposal, Art 16(3)).

${ }^{69} \mathrm{~F}$ Lutz, 'Prologue', in this volume.
} 
